\title{
ANALISIS AKTIVITAS PEMBELAJARAN BIOLOGI PADA GOOGLE CLASSROOM DI MASA PANDEMI COVID-19
}

\author{
Arista Indah Anggraini ${ }^{1}$, Suwarto ${ }^{2 *}$, Dudy Iskandar ${ }^{3}$ \\ Mahasiswa Pendidikan Biologi Universitas Veteran Bangun Nusantara Sukoharjo ${ }^{1}$ \\ Dosen Universitas Veteran Bangun Nusantara Sukoharjo ${ }^{2}$ \\ Guru SMA Negeri 1 Tawangsari Kabupaten Sukoharjo ${ }^{3}$ \\ e-mail: suwartowarto@yahoo.com*
}

\begin{abstract}
ABSTRAK
Penelitian ini bertujuan untuk mengetahui bagaimana analisis aktivitas pembelajaran biologi pada materi virus berbasis daring (melalui aplikasi Google Clasroom) di masa Pandemic Covid19 pada siswa kelas X IPS 3 di SMA N 1 Tawangsari. Jenis penelitian menggunakan kualitatif deskripstif, karena penulis tidak membuktikan ataupun menolak hipotesis yang dibuat sebelum penulisan tetapi dalam mengolah data dan menganalisis suatu masalah secara non numerik, metode pengambilan data menggunakan wawancara, lembar observasi dan dokumentasi dalam melihat aktivitas pembelajaran biologi selama masa Pandemic Covid-19. Hasil penelitian ini bertujuan untuk melihat bagaimana perencanaan aktivitas pembelajaran, proses pembelajaran dan penilaian aktivitas pembelajaran selama masa Pandemic Covid-19.
\end{abstract}

Kata kunci: pandemi Covid-19, pembelajaran daring, pelajaran biologi

\section{PENDAHULUAN}

Menurut Undang Undang Republik Indonesia Nomor 20 Tahun 2003 Tentang Sistem Pendidikan Nasional menyatakan bahwa "Pendidikan adalah usaha sadar dan terencana untuk mewujudkan suasana belajar dan proses pembelajaran agar peserta didik secara aktif mengembangkan potesi dirinya untuk memiliki kekuatan spiritual keagamaan, pengendalian diri, kepribadian, kecerdasan, akhlak mulia, serta keterampilan yang diperlukan dirinya dimasyarakat". Pendidikan tidak akan lepas dari belajar, belajar merupakan suatu usaha untuk memperoleh pengetahuan (ilmu), meningkatkan keterampilan, memperbaiki prilaku, sikap dan mengokohkan kepribadian.

Wabah Novel Corona Virus Disease 2019 (Covid-19) menyerang Wuhan China dan dengan cepat menyebar ke seluruh dunia. Pandemi dinyatakan ketika penyakit baru menyebar di seluruh dunia melampaui batas. World Health Organization (WHO) sebagai organisasi kesehatan dunia telah mendeklarasikan kejadian ini sebagai pandemi global di bulan Desember 2019 (Baskara, 2020). Hal tersebut mengharuskan kita untuk 
melakukan karantina secara mandiri di rumah untuk memutus rantai penyebaran dari virus tersebut. Keadaan ini menyebabkan seluruh kegiatan dalam berbagai sektor menjadi terhambat, salah satunya dalam sektor pendidikan.

Pandemi Covid-19 sejak Maret 2020 memaksa semua negara menerapkan social distancing dan physical distancing untuk mencegah penyebarannya. Data sampai akhir bulan Agustus 2020 menyatakan lebih dari 23 juta orang terinfeksi virus ini dengan jumlah kematian diseluruh dunia mencapai 812 ribu orang lebih. (Worldometers, 2020).

Pandemi ini juga memberi pengaruh dalam aspek pendidikan terhadap kegiatan belajar mengajar. Seluruh institusi pendidikan diseluruh dunia terpaksa menghentikan belajar tatap muka dan menggantinya dengan daring. Model pembelajaran berbasis daring terpaksa dilakukan agar penyebaran virus ini tidak berlangsung cepat (Mesran et al.,2020), diyakini bahwa penggunaan teknologi dalam pembelajaran (Suwarto, 2009, 2017).

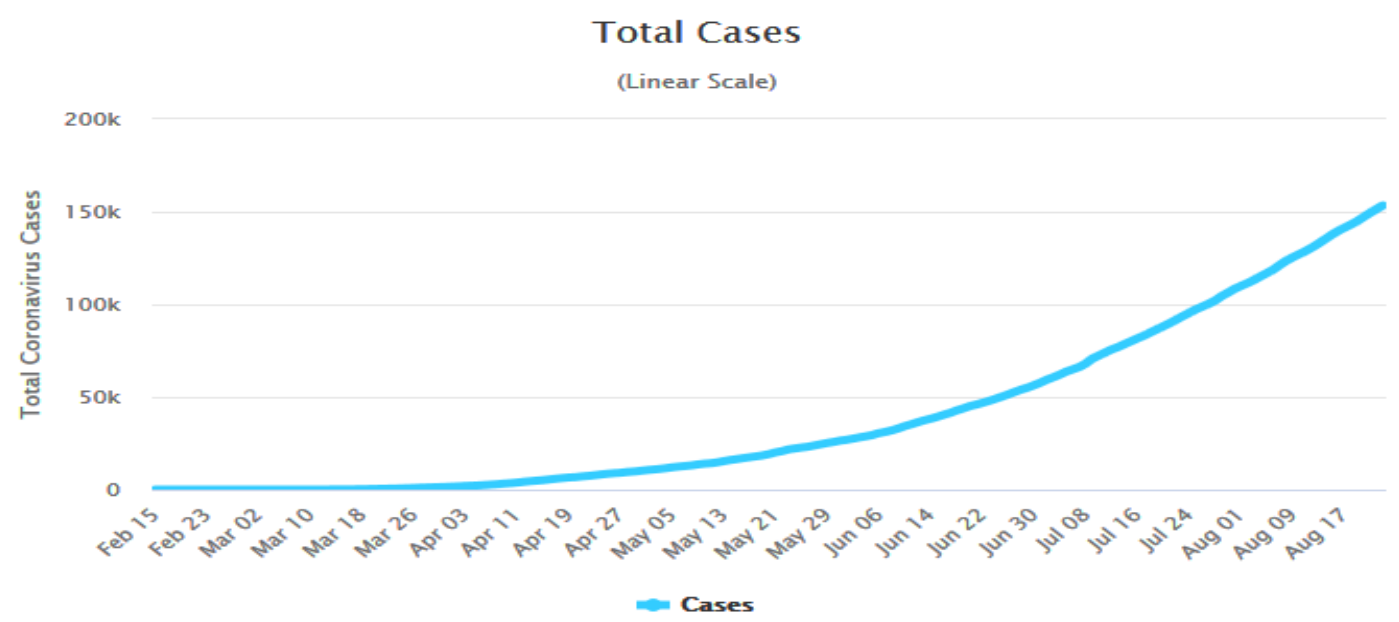

Gambar 1. Jumlah kasus penyebaran Covid19 sampai bulan Agustus di Indonesia (Worldometers, 2020)

Nadiem Makarim selaku Kementerian Pendidikan dan Kebudayaan, merespon cepat pencegahan pandemi ini dengan mengeluarkan kebijakan tentang pelaksanaan pendidikan dalam masa darurat penyebaran virus Covid-19. Kebijakan tersebut menjelaskan tentang pelaksanaan Proses Belajar Dari Rumah (BDR) dengan bentuk pembelajaran dilakukan melalui jarak jauh atau daring menggunakan jaringan internet dengan bantuan alat perantara seperti handphone, gadget, komputer, atau laptop. (Maris, 2020).

Menurut Bujang bentuk pembelajaran daring pada saat ini berkembang pesat dengan berbagai istilah dan penerapannya seperti online learning, mobile learning, webbased learning, atau electronic-learning (elearning). E-learning bahkan dianggap pendidikan masa depan (Pendidikan 4.0) dengan penggunaan platform dan alat digital 
yang mendorong keterlibatan siswa dan guru untuk memiliki kecakapan digital dan ICT (Bujang et al., 2020).

Berdasarkan penelitian yang dilakukan oleh Hanum, e-learning adalah cara baru pembelajaran dengan akses internet untuk meningkatkan lingkungan belajar tanpa harus datang ke ruangan kelas, dapat diakses dimana saja, dan kapan saja selama memiliki jaringan internet. Sehingga dengan memanfaatkan internet mahasiswa dapat memperluas lingkungan belajarnya dengan konten yang kaya dengan cakupan yang luas (Hanum, 2013).

Akibat kebijakan pelaksanaan pendidikan tentang pelaksanaan Proses Belajar Dari Rumah (BDR) dengan bentuk pembelajaran dilakukan melalui jarak jauh atau daring. Aktivitas pembelajaran biologi adalah suatu proses pemberian pengalaman belajar kepada peserta didik melalui serangkaian kegiatan yang terencana sehingga peserta didik memperoleh pengetahuan mengenai materi yang dipelajari (Firman, 2020); (Imaniar, 2019). Materi yang dipelajari adalah virus, definisi virus adalah parasit yang berukuran mikroskopik yang mengifeksi sel rganisme biologis, virus hanya dapat bereproduksi di dalam material hidup dengan memanfaatkan sel makhluk hidup karena virus tidak memiliki perlengkapan selular untuk bereproduksi sendiri.

Terjadinya pandemi Covid-19 di Indonesia, memaksa SMA Negeri 1 Tawangsari kelas X IPS 3 pada materi pembelajaran biologi untuk menerapkan pembelajaran daring secara intensif. Namun penerapan ini perlu dievaluasi agar diketahui bentuk pembelajaran daring seperti apa yang diinginkan siswa (Arizona, Abidin, \& Rumansyah, 2020). Hasil evaluasi merupakan tujuan dalam penelitian ini dalam memahami persepsi siswa dalam mempelajari materi biologi sel berdasarkan pembelajaran berbasis daring (Mu'minah, 2020).

SMA Negeri 1 Tawangsari salah satu sekolah di Sukoharjo yang sudah menerapan e-learning. Izenstark dan Leahy mengatakan bahwa Google Classroom adalah salah satu bentuk penerapan e-learning yang dilakukan oleh Universitas Islam Indonesia. Layanan portal Google Classroom dengan alamat https://classroom.google.com/ hanya dapat diakses oleh guru dan siswa yang memiliki akses masuk. Google Classroom memiliki fitur-fitur pendukung yang terhubung dengan Google Apps for Education diantaranya Gmail, Youtube, Google Drive, Google Maps, dan Google Translate. Hal ini memudahkan siswa karena konektivitas antara Google Classroom dengan akun Google Drive. Siswa tidak perlu khawatir untuk menyimpan dokumen-dokumen dalam komputer kelas dikarenakan dengan fitur menyimpan secara otomatis dan kegunaan dari Google Drive membuat tugas menjadi lebih mudah disimpan dan terorganisir (Izenstark dan Leahy, 2015).

Bentuk pecegahan dari penularan covid-19 ini dengan diberlakukannya pembatasan disegala sektor melalui kementrian kesehatan membuat peraturan pemerintah Nomor 21 Tahun 2020 tentang Pembatasan Sosial Berskala Besar, akibatnya proses pembelajaran di Sekolah menjadi terhambat sehingga pembelajaran yang 
semula disekolah beralih menjadi pembelajaran di rumah, salah satu contoh di SMA Negeri 1 Tawangsari guru melakukan pembelajaran melalui aplikasi google classsroom, ini dipandang karena google classroom dapat memudahkan guru dan siswa tanpa harus bertatap muka dan mudah digunakan. Berdasarkan apa yang telah dipaparkan tujuan dari penelitian adalah untuk menganalisis aktivitas pembelajaran biologi pada materi virus di masa Pandemi Covid-19 pada siswa kelas IPS 3 di SMA Negeri 1 Tawangsari. Sedangkan rumusan masalahnya adalah melihat bagaimana perencanaan aktivitas pembelajaran, aktivitas pembelajaran dan penilaian aktivitas pembelajaran biologi selama masa Pandemi Covid-19 dengan menggunakan beberapa pedoman untuk memenuhi penelitian ini.

\section{METODE PENELITIAN}

Menurut Mantra (2004) dalam buku Siyoto S (2015: 27) mengemukakan metode kualitatif sebagai prosedur penelitian yang menghasilkan data deskriptif berupa katakata atau lisan dari orang orang dan perilaku yang dapat diamati. Metode kualitatif berusaha mengungkap berbagai keunikan yang terdapat dalam individu, kelompok, masyarakat, dan/atau organisasi dalam kehidupan seharihari secara menyeluruh, rinci, dalam, dan dapat dipertanggungjawabkan secara ilmiah.

Instrumen yang digunakan dalam penelitian ini adalah penulis itu sendiri, pedoman wawancara, dan dokumentasi penulis yang melihat proses pembelajaran melalui aplikasi Google Classroom mengubah siklus subjek yang diteliti dan menulis semua yang terjadi pada saat proses monitoring melalui aplikasi Google Classroom serta mewawancarai guru dan peserta didik perihal hambatan saat aktivitas pembelajaran dimasa Pandemi Covid-19 ini.

Metode wawancara yang digunakan oleh peneliti adalah wawancara semiterstruktur dalam hal ini mula-mula interviwer mananyakan serentetan pertanyaan yang sudah terstruktur, kemudian satu per satu diperdalam dalam mengorek keterangan lebih lanjut. Dengan demikian jawaban yang diperoleh bisa meliputi semua variabel, dengan keterangan yang lengkap dan mendalam Siyoto $S$ (2015: 75) tujuan dalam wawancara ini penulis ingin menemukan permasalahan dimana pihak yang diwawancarai dalam hal ini guru dan siswa diajak untuk berpendapat mengenai permasalahan yang dihadapi dalam proses aktivitas pembelajaran dimasa Pandemi Covid-19 ini maupun secara daring.

Pengumpulan data dalam penelitian ini berupa observasi, Siyoto S (2015: 76). Observasi yang dilakukan mengikuti waktu dan jadwal mata pelajaran biologi dikelas $\mathrm{X}$ IPS 3 melalui Google Classroom yang menjadi sarana dalam proses aktivitas pembelajaran dimasa Pandemi Covid-19. 


\section{HASIL PENELITIAN DAN PEMBAHASAN}

Penelitian ini dilakukan di rumah, karena mengingat kondisi saat ini yang sedang ada wabah Covid-19. Aktivitas pembelajaran di SMA N 1 Tawangsari selama pandemi ini berjalan seperti biasa, pembelajaran dimulai jam 07.00 WIB sampai selesai jam 15.30 WIB. Pembelajaran menggunakan aplikasi google classroom sangat mendukung pada masa pandemi ini, karena memberikan kemudahan akses bagi peserta didik terhadap materi ajar tanpa harus bertatap muka (Suhada, Kurniati, Pramadi, \& Listiawati, 2020). Demikian juga halnya yang diungkap oleh Mu'minah, \& Gaffar (2020). Akan tetapi tidak semua pembelajaran berjalan secara efektif, karena kondisi ketersediaan jaringan peserta didik yang berbeda dan keterbatasan kuota peserta didik (Fernando, 2020).

Pada saat dilakukan wawancara dengan narasumber guru dan 10 peserta didik yang dilakukan menggunakan aplikasi Google Classroom dengan mengirimkan link dan meminta tanggapan peserta didik pada saat melaksanakan aktivitas pembelajaran dari rumah dengan menggunakan aplikasi google classroom (Rikizaputra, \& Sulastri, 2020). Pelaksanaan pembelajaran sama seperti saat dikelas hanya saja model pembelajaran dengan menggunakan PPT dabing yang telah dijelaskan guru serta dikirim di google classroom, kemudian untuk tugas hampir sama namun umpan baliknya peserta didik harus mengumpulkan tugas ke Google Classroom juga untuk dinilai guru dalam tenggang waktu yang ditentukan.

Perencanaan aktivitas pembelajaran biologi dimasa pandemi yaitu RPP dan bahan ajar sesuai dengan materi yang telah disampaikan sebelumnya oleh guru kepada peserta didik saat pembelajaran sebelumnya di google classroom memberikan penjelasan materi menggunakan PPT dabing, dan juga selalu mengingatkan mengenai perilaku hidup sehat dimasa pandemi seperti ini.

Dalam penilaian pengetahuan guru memberikan nilai dengan cara melihat kemampuan peserta didik dalam mengerjakan tugas, penilaian ketrampila guru akan menilai menggunakan teknik unjuk kerja, dengan cara peserta didik menuliskan cara atau jawaban yang telah didapat siswa dengan menuliskan langkah-langkahnya.

Berdasarkan hasil dan pembahasan diatas penelitian ini menjelaskan bagaimana aktivitas pembelajaran pada mata pelajaran biologi dengan materi dikelas X IPS 3 yang dilaksanakan oleh guru dan peserta didik menggunakan wawancara, observasi, dan dokumentasi untuk mengumpulkan data-data mengungkapkan bagaimana aktivitas pembelajaran yang terjadi selama masa pandemic Covid-19.

\section{KESIMPULAN}

Berdasarkan hasil penelitian diatas dapat disimpulkan bahwa dalam perencanaan aktivitas pembelajaran biologi selama masa Pandemi Covid-19 dikelas $X$ IPS 3 SMA N 1 Tawangsari guru membuat RPP daring atau PJJ dengan berpedoman pada surat edaran Menteri Pendidikan dan Kebudayaan No.14 Tahun 2019 dengan 
didalamnya memuat nilai nilai karakter, dan materi sesuai dengan yang telah dipelajari hal ini berkaitan dengan materi disemester 1 yaitu materi virus. Dalam Aktivitas pembelajaran biologi selama masa Pandemi Covid-19 dilaksanakan pembelajaran dari rumah melalui Aplikasi Google Classroom. Guru hanya memberikan penjelasan dan tugas, tidak ada metode khusus yang guru. Sistem penilaian meliputi: sikap, pengetahuan dan keterampilan. Aktivitas siswa dalam mengerjakan tugas secara individu dan ada juga yang dibantu oleh orang tua, saudara atau temen dekat peserta didik.

\section{SARAN}

Saran penelitian lebih lanjut untuk meneliti aktivitas pembelajaran pada bidang studi yang lain terkait dengan pembelajaran melalui Google Classroom disaat pandemi Covid-19 ini.

\section{DAFTAR PUSTAKA}

Arizona, K., Abidin, Z., \& Rumansyah, R. (2020). Pembelajaran Online Berbasis Proyek Salah Satu Solusi Kegiatan Belajar Mengajar Di Tengah Pandemi Covid-19. Jurnal IImiah Profesi pendidikan, 5(1), 64-70.

Baskara, B. (2020). Rangkaian Peristiwa Pertama Covid-19. Kompas.Id, 1-1. https://bebas.kompas.id/baca/riset/2020/04/18/rangkaian-peristiwa-pertamacovid-19/

Bujang, S. D. A., Selamat, A., Krejcar, O., Maresova, P., \& Nguyen, N. T. (2020). Digital Learning Demand for Future Education 4.0-Case Studies at Malaysia Education Institutions. Informatics, 7(2), 13. https://doi.org/10.3390/informatics70 20013.

Fernando, A. (2020). Respon Mahasiswa terhadap Proses Pembelajaran Biologi Melalui Google Classroom di Universitas Maritim Raja Ali Haji. Pedagogi Hayati, 4(1), 1018.

Firman, F. (2020). Dampak Covid-19 terhadap Pembelajaran di Perguruan Tinggi. BIOMA: Jurnal Biologi dan Pembelajarannya, 2(1), 14-20.

Hanum, N. S. (2013). Keefetifan e-learning sebagai media pembelajaran (studi evaluasi model pembelajaran e-learning SMK Telkom Sandhy Putra Purwokerto). Jurnal Pendidikan Vokasi, 3(1), 90-102. https://doi.org/10.21831/jpv.v3i1.1584

Hidayat, M. L., \& Nurcahyanto, G. (2018). Analisis Kesesuaian Google Classroom sebagai LMS pada Mata Kuliah Strategi Pembelajaran Biologi di FKIP UMS. In Proceeding Biology Education Conference: Biology, Science, Enviromental, and Learning (Vol. 15 , No. 1, pp. 572-576) 
Imaniar, N. T. (2019). Analisis Keterampilan Proses Sains Dalam Penerapan Project Based Learning Berbantuan Google Classroom Bagi Siswa Kelas XI (Doctoral dissertation, Universitas Negeri Semarang).

Izenstark, Amanda, and Katie L. Leahy. (2015). Google Classroom for Librarians: Features and Opportunities. Library Hi Tech News 32 (9):1-3. https://doi.org/10.1108/LHTN-05-2015-0039.

Maris, S. (2020). Enam Kebijakan Kemendikbud dalam Masa Darurat Covid-19. Www.Liputan6.Com. https://www.liputan6.com/news/read /4227701/enamkebijakan- kemendikbud-dalam-masa-darurat- covid-19.

Mesran, Sulaiman, O. K., Wijoyo, H., Putra, S. H., Watrianthos, R., Sinaga, R., Mardiana, R., Saragih, M. G., \& Indarto, S. L. (2020). Merdeka Kreatif di Era Pandemi Covid-19: Suatu Pengantar. Green Press.

Mu'minah, I. H. (2020). Optimalisasi Penggunaan Google Classroom Sebagai Alternatif Digitalisasi Dalam Pembelajaran Jarak Jauh (PJJ). BIO EDUCATIO:(The Journal of Science and Biology Education), 5(2).

Mu'minah, I. H., \& Gaffar, A. A. (2020, November). Pemanfaatan E-Learning Berbasis Google Classroom Sebagai Media Pembelajaran Biologi. In Prosiding Seminar Nasional Pendidikan (Vol. 2, pp. 800-816).

Rikizaputra, R., \& Sulastri, H. (2020). Pengaruh E-Learning dengan Google Classroom terhadap Hasil dan Motivasi Belajar Biologi Siswa. Lectura: Jurnal Pendidikan, 11(1).

Suhada, I., Kurniati, T., Pramadi, A., \& Listiawati, M. (2020). Pembelajaran daring berbasis Google Classroom mahasiswa pendidikan biologi pada masa wabah Covid-19. Digital Library UIN Sunan Gunung Djati, 1-10.

Suwarto, S. (2009). Pengembangan tes dan analisis hasil tes yang terintegrasi dalam program komputer. Jurnal Penelitian dan Evaluasi Pendidikan, 13(1).

Suwarto, S. (2017). Pengembangan tes ilmu pengetahuan alam terkomputerisasi. Jurnal Penelitian dan Evaluasi Pendidikan, 21(2), 153-161.

Worldometers. (2020). COVID-19 Coronavirus Pandemic. Worldometers.Info2. https://www.worldometers.info/coro navirus/?utm_campaign=homeAdveg as1?. 